\title{
A blikk diagnózisról
}

\author{
Simon Kornél dr.
}

Siófoki Kórház-Rendelőintézet, Siófok

\section{Mit jelent a blikk diagnózis?}

Ránézek valamire, heuréka!-érzésem támad, és tudni vélem a kórismét. A látás, az érzés, a gondolat egymásutániságával jellemezhető folyamat semmiképp nem köthetô a logikai gondolkodáshoz, hanem egyértelmúen az analóg asszociációhoz. A blikk diagnózis és a felfedezésélmény között ezért egyértelmű rokonság állapítható meg, annál is inkább, mert a felfedezések döntő többsége nem logikai úton, hanem analóg gondolkodás eredményeként született.

A blikk diagnózis jogosultságával, használhatóságával kapcsolatban az alábbi kérdések merülnek fel: Van-e valóságtartalma? Ha igen, mitől függ a valóságtartalma? Van-e tudományos magyarázata, tudományosan elfogadható, vagy éppen elvetendő a blikk diagnózis?

1988-ban pár hónapot a torontói St. Michael's Hospital kardiológiai klinikáján töltöttem Rékai-ösztöndíjasként. A klinika Paul Amstrong professzor nevével fémjelzett, világszerte elismert központja volt az ischaemiás szívbetegségeknek. Az egyik viziten egy frissen érkezett olasz kolléga véleményét kérdezték az egyik betegről, aki - miután a betegre nézett - mondanivalóját így kezdte: „Vesebetegról van szó, aki...” A szuperspecialista, objektiv paraméterekhez szokott kardiológusok reakciója lekezelő, sőt elutasító volt: a szubjektív kijelentést megalapozatlannak, szinte szélhámosságnak titulálták. Az evidenciákhoz szokott mai tudományszemlélet számára a blikk diagnózis nem elfogadható, tudománytalan módszer.

\section{A blikk diagnózis ismeretelméleti vonatkozásai}

A blikk diagnózis kulcsmozzanata a blikk: a látás. Valóban a látás és a megértés kölcsönösen támogató viszonya létezik: amit látunk, azt jobban értjük, és megfordítva, amit értünk, azt többnyire vizuálisan is el tudjuk képzelni.

Egy példa a látás, az „egyben látás” és az értés kapcsolatára. A szív Doppler-ultrahangos mozgóképes felvételének megtekintése (1. ábra-mozgóábra), a holisztikus egyben látás - minden egyéb adat ismerete nélkül is egyfajta „értem!-érzést” eredményez: az anatómiai információn kívül egy határozott funkcionális benyomást is ad. Ha pedig ugyanezen szív MR-felvételét is megtekintjük (2. ábra-mozgóábra), akkor a szemlélőben akár egy intuitív ötlet is joggal megfogalmazódhat: a látott kép kétséget támaszthat arról, hogy a szív nyomásgenerátor lenne, sokkal inkább tűnik - a szívüregekben látható intenzív áramlást látva - keringésgenerátornak. Megemlítendő, hogy a tankönyvekben a szívciklus alatti üregi áramlásokról nem történik említés.

Ugyanakkor nemcsak a látás, hanem egyéb percepciós élmények is képesek asszociációkat, „tudatalatti” gondolatokat előhívni. Szentágothai professzor mesélte el az alábbi történetet az egyik tantermi előadásán: Gyermekkorában Svájcban tanult egy internátusban, ahová hoszszú évek után fiatal felnőtt korában látogatott el újra. Odaérkezése előtt próbálta az ott szerzett élményeit felidézni, de nem járt sikerrel. Amikor belépett az internátus halljába és megérezte a faborítás speciális illatát, az emlékek sora idéződött fel benne. A példát a hypocampus - mint szaglásközpont - és az egyéb agyi áreák közti kapcsolatok demonstrálására szánta.

Fiatal pécsi orvosként egy éjszakai ügyeletben a következő történt. Pár Alajos tanársegéd - ügyeletvezető egy hasi panaszokkal frissen érkezett beteg ágya mellett ült. Nem tudta még a beteg baját, „ezért” pár percenként újra és újra megmérte a vérnyomását és számolta a beteg pulzusát. Nem azért tette mindezt, mert ezek a paraméterek változtak volna, hanem azért - gondolom utólag -, mert a komplex percepciótól: a látás, a hallás, a tapintás, a szaglás együttes élményétől, a beteggel való együttléttől - és nem elrendelt újabb vizsgálatok eredményétől - várta a heuréka!-ráérzést, a diagnózisra vezető asszociációt. Másképpen fogalmazva: az Egész holisztikus észlelését alkalmazta a részletek vizsgálatával szemben.

A „holisztikus egyben látás” élménnyel ellentétes másik véglet ugyanis a részletekbe felejtkezés.

1998-ban Székesfehérváron egy klinikopatológiai konferencián a szemész és a patológus az alábbi kórese-

Az 1. mozgóábra (A „8”-as áramlás Doppler-echoképe) és a 2. mozgóábra (A „8”-as áramlás szív-MRképe) elérhetósége:

https://www.dropbox.com/s/sdmlcbgacus244d/ blikk_dg.ppt?dl=0 


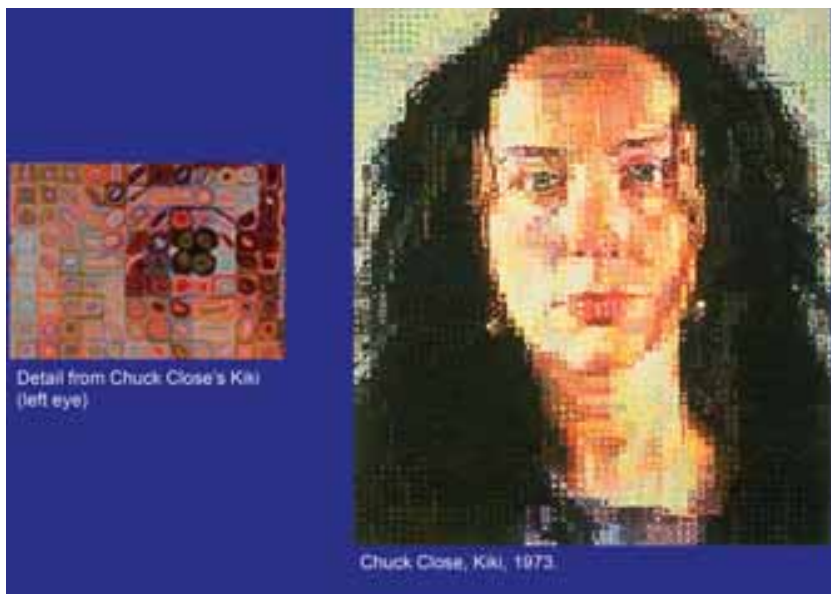

3. ábra

| Kiki bal szeme és arcképe [14]

tet mutatta be. Egy nóbeteg corneáján keletkezett növedékből a szemész kimetszett, a patológus megvizsgálta és megállapította a szövettan alapján, hogy a betegnek emlőrákja van. Ez kétségtelen bravúros teljesítmény. E dicsőség jogosságát kétségbe vonta azonban az a hozzászóló, aki megjegyezte: „Ha ezt a beteget valaki megvizsgálta volna, nem lett volna szükség a bravúrra.” $\mathrm{Az}$ „egyben látás” gyakorta egyszerúbben vezet eredményre, mint a részletek bonyolult vizsgálata.

Ha valaki bemegy az intenzív osztályra, hogy egy súlyos beteg aktuális állapotáról érdeklődjön, és megkérdez egy jól képzett orvost, akkor válaszul - nemritkán egy sor friss laboratóriumi, képalkotási és egyéb vizsgálati adat felsorolását kapja. Ha ugyanezt a kérdést egy tapasztalt nővérnek teszi fel, akkor a válasz többnyire így hangzik: „jobban van”, vagy „rosszabbul van”. A számos részletre vonatkozó adattömeg léte azzal fenyegethet, hogy elmarad a szintézis. A részletek aprólékos vizsgálata gátolhatja a holisztikus egyben látást.

Ha Kiki arcképének bal szemét kinagyítva nézzük (3. ábra), akkor köröket, háromszögeket, négyzeteket látunk egymás mellett. Esélyünk nincs arra, hogy az egész kép jelentését megtudjuk. A részletekbe való felejtkezés meggátolja az Egész felismerését. Ha valakinek ősz hajszálai vannak - és ezek önmagukban kétséget kizáróan bizonyító erejűek is -, nem jelenthető ki, hogy az illető egészében ősz lenne. A részlet hangsúlyozása, önmagában való észlelése hamis következtetésre vezethet. A valóság feltárásához a holisztikus egyben látás nem nélkülözhető.

E példák paradoxonjainak tudatában megalapozottnak tűnik Mess Béla emeritus professzor megállapítása: „Vannak horizontális, és vannak vertikális kutatók. Utóbbiak olyan mélyre képesek magukat ásni, hogy onnan már ki sem látnak." Szirmai Imre professzor így fogalmazott: „Akinek nincs több ötlete, az specializálódik.” Szerintem az ellentéte is igaz: „Aki specializálódik, annak nem igazán lesz több ötlete."

Ezen idézetek az úgynevezett redukcionista, illetve holisztikus tudományos felfogás ellentétére utalnak. Sőt a fenti példák „az ördög a részletekben van” megfogalmazás igazságára utalnak, aminek ellentéte: „az Isten az Egészben van" jelenti a többet. Másképpen fogalmazva: a holisztikus látásmód nélkülözhetetlen a valóság megismerésében.

A vitorlázás elméleti oktatása során részletes információkat kap a jelölt a szélirány, a szélerősség, a hajó kormánylapátállásának, a vitorlázat állásának, a tervezett haladási cél, a hajó tulajdonságainak, a személyzet teendőinek bonyolult összefüggéseiről. Ezek az ismeretek külön-külön mind-mind elmagyarázhatók, megérthetők, a vizsgán kikérdezhetők, de amíg mindezen ismeretek nem egyesülnek egy „komplex zsigeri érzéssé”, addig a vitorlázás gyakorlati tudása nem valósul meg. Hamvas Béla „A szakácsmúvészet” címú írásában így fogalmaz: „a szakács a kést félretette és így válaszolt: Ma már teljesen érzületeimre bízom magam. Szememmel nem is törődöm. Az érzékek ismereteit feladtam, csak a szellem mozdulataira figyelek. Csak a törvényt látom” (»érzem«).

Van-e ennek analógiája a klinikai gyakorlatban? Dr. Dock amerikai orvos a múlt század első felében egy betegénél a szív felett diasztolés zörejt hallott, amit a fonokardiogramon nem tudott azonosítani sem a mitralis stenosis, sem az aortabillentyű elégtelenségének zörejével. Tekintettel arra, hogy a beteg angina pectorisban szenvedett, dr. Dock - tudva azt, hogy a bal kamrában keringés csak a diasztolé alatt van - úgy gondolta, hogy a bal coronaria leszálló ágában lévő stenosis okozta zörejt hallja. A beteg elhalálozott, a boncolás pedig igazolta a feltételezést. Dock dr. tehát nem a készen kapott koronarogram megtekintése alapján jutott a diagnózishoz, hanem - bizonyos adatok logikai szintézise útján lelki szemeivel alkotott egy koronarogramot, azaz a részismereteket rakta össze egy vizuális kép formájában.

Romhányi professzor szellemében fogalmazható meg a „biológiai iránytü" fogalma: a számos részletekbe menő adat megértését követően a szintetikus, integráló gondolkodás eredményeképp létrejön a belső látással megalkotott kép. A klasszikus fizikális vizsgálat (inspekció, tapintás, kopogtatás, hallgatózás) „értelme” nem más, mint - indirekt információk alapján - a szervekről vizuális lelki képet alkotni.

Romhányi professzor gyakorta idézett tanítása: „fele játék, fele gyötrelem", a fenti vonatkozásban is értelmezhető: a gyötrelem az, amikor valaki verejtékes munkával a részletekből rekonstruálja az Egészet, a játék pedig az, amikor használja a „biológiai iránytüjét”: azaz olyan területen is tájékozódni tud, ahol még soha nem járt.

Mi kell még az ötlethez, mi kell még a felfedezéshez? Mi kell még a biológiai iránytü megszületéséhez? Az, hogy az észlelés során azon információkra fordítódjon a figyelem, amelyek nem illenek bele az a priori elképzelésbe. Azaz, valóban az észlelés irányítsa a megfigyelést, és nem megfordítva, amikor csak azon adatok kerülnek „észlelésre”, amelyek támogatják a nullhipotézist. Az észlelést végző egyén tudatállapota legyen percepcióra 


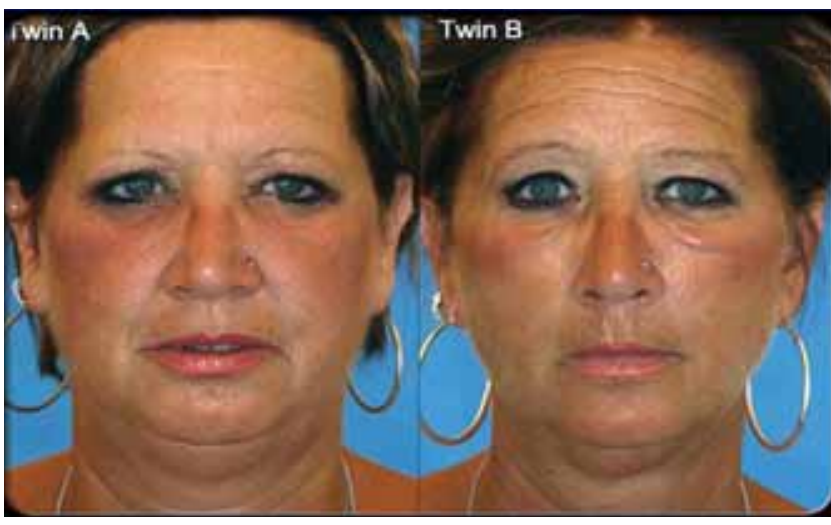

4. ábra | Ikerpár nem dohányzó és dohányzó tagja

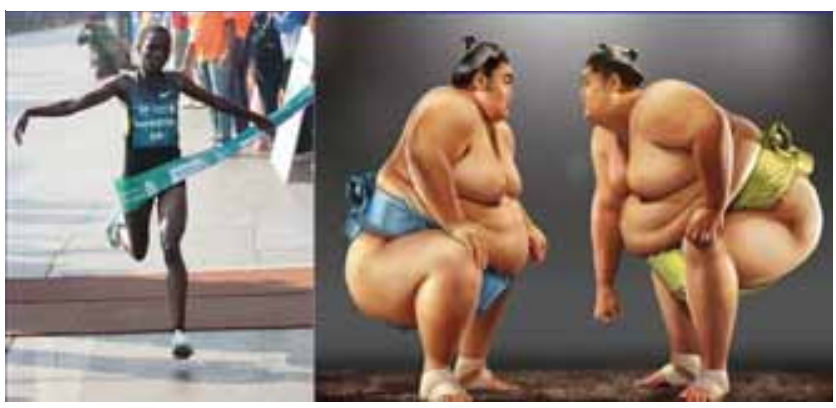

5. ábra

| Maratoni futó és szumóharcosok

érzékeny, befogadó, rugalmas, ne pedig merev, projektív és érzéketlenül elutasító.

Székesfehérvári múködésem alatt egy alkalommal a velünk évek óta együtt dolgozó takarítónő munkatársam fordult hozzám akut panaszai miatt. A fizikális vizsgálat során meglepetéssel konstatáltam, hogy a munkatársam típusos Turner-szindrómás alkattal rendelkezik. Ennek megállapításához „más szemmel - orvosszemmel - kellett ránézni”.

Ugyancsak fehérvári tartózkodásom alatt tûnt fel, hogy a legszebb, legtanulságosabb esetek mindig szombat-vasárnap vagy az éjszakai ügyelet alatt kerültek észlelésre. Ezt a tényt - nem teljes komolysággal, de biztató szándékkal - így fogalmaztam meg munkatársaimnak: „látod a jóisten megjutalmazott azért, mert munkaidőn túl is itt maradtál". Aztán megszületett a valószínú magyarázat: a munkaidőn kívüli jelenlét esetén nem kellett rohanni, nem az adott idő alatt kellett a vizitet befejezni, volt idő a beteget meghallgatni, valóban a percepció irányította az észlelőt, nem pedig a már meglévő a priori ítélet. Ez kiváltképp igaz az éjszakai, kiélezett, döntéskényszerü helyzetben. Romhányi professzor szokta mondani: „A szükség a legjobb inspirátor.” Majd ránézett a medikusra, és biztatóan mondta: „Úgy, hogy még te is lehetsz okos."

A blikk diagnózis és a felfedezés analógiájára visszatérve, Romhányi professzor így fogalmazott: „A felfedezés soha nem az igyekvés centrumában van, hanem a perifé- riás látótérben. Ott, ahová eredetileg nem is figyeltünk.” A felfedezés valószínúségéről ezért hangsúlyozta: „felkészültség és alázat”. Az alázatról így beszélt: „Jó kérdést kell feltenni a természetnek, és az válaszol. Miként jó kérdést kell feltenni a betegnek, és ő is válaszol.” A felkészültségről így vallott: „A jó kérdést feltenni a legnehezebb. Az élére állított kérdést már sokkal könnyebb eldönteni.” A felfedezések „kulcsa” serendipity-ról pedig így vallott: „A véletlen csak a felkészült elmét lepi meg.” Példaként Kekület emlegette: a tudat alatti figyelem minden idegszálával a megoldatlan, élére állított kérdésre koncentrál. Még álmában is. És akkor jön a véletlen: a kígyó megharapja a farkát: a nyílt szénláncúnak hitt 6 szénatom benzolgyưrưvé zárul. Ez a gyưrüs szerkezetú szénlánc felfedezésének anekdotája.

\section{A blikk diagnózis tudományos alapjáról}

Az élet nem más, mint egy - a bölcsőtől a sírig tartó folyamatos interakció a szervezet és a környezet között. Az interakció neve a Selye-féle stresszadaptáció $[1,2]$. Az interakció célja a szervezet megóvása az ártalmas noxától. Az akut stressz során a szervezet vagy legyőzi az ártalmat, vagy elmenekül (flight or fight reakció). A krónikus stressz során a szervezet - mivel nem tudja az ártalmat eltávolítani - alkalmazkodik hozzá. Ennek az interakciónak a tétje nem kevesebb, mint az egészség vagy a betegség, végső soron az élet vagy a halál.

A stresszadaptáció főszereplői a genom és az epigenetika. Hasonlattal élve: a zongora húrspektruma felel meg a génállománynak, a zongorista az epigenetikának, a lejátszott dallam pedig a külső megjelenésnek, a fenotípusnak. Ahogy ugyanazon a zongorán nagyon sokféle dallam játszható, ugyanúgy - ugyanazon genom esetén is - számos fenotípus hívható elő. Identikus genommal rendelkező egypetéjú ikrek esetén is nagyon különböző lehet a felnőttkori fenotípus (dyscordans fenotípus). Például akkor, ha az ikerpár egyik tagja gyermekkorában akut lymphoblastos leukaemiában szenvedett, és ezért kemoterápiában, illetve koponyairradiációban részesült [3]. Más volt a belső környezet (az akut leukaemia), és más volt a külső környezet (kemoterápia, koponyairradiáció), azaz más volt a kotta, ezért a zongorista kénytelen volt más dallamot játszani. Nyilvánvaló a példából, hogy a fenotípust sokkal inkább az epigenetika, mint a genom határozza meg.

A „selyei környezet” $[2,4]$, a kotta fogalmába tehát beletartozik a külső környezet (fizikai, kémiai, biológiai ártalmak), a különböző kórformák okozta specifikus miliő alkotta belső környezet, és speciális belső környezetet jelent a pszichomentális állapot is.

Mindezen környezeti tényezők határozzák meg a fenotípus alakulását. Például egypetéjű ikrek esetén a dohányos ikerpár fenotípusa a nikotin okozta specifikus, külső környezeti hatás miatt különbözik a nem dohányzó ikerpár fenotípusától (4. ábra). A maratoni futó és a szumóharcosok fenotípusa is jelentősen különbözik 


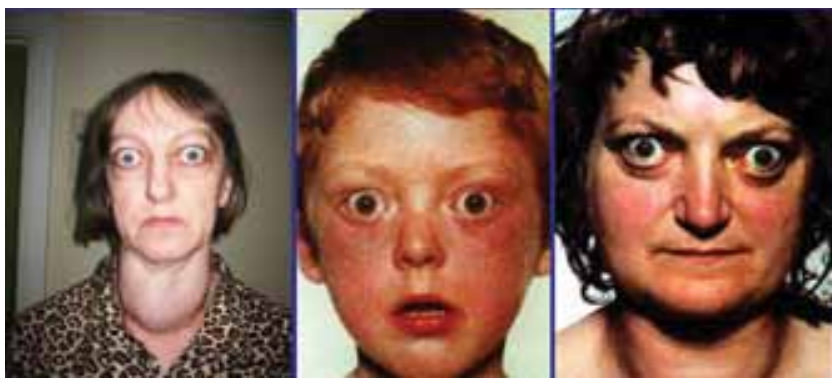

6. ábra | Hyperthyreosisra jellemző facies
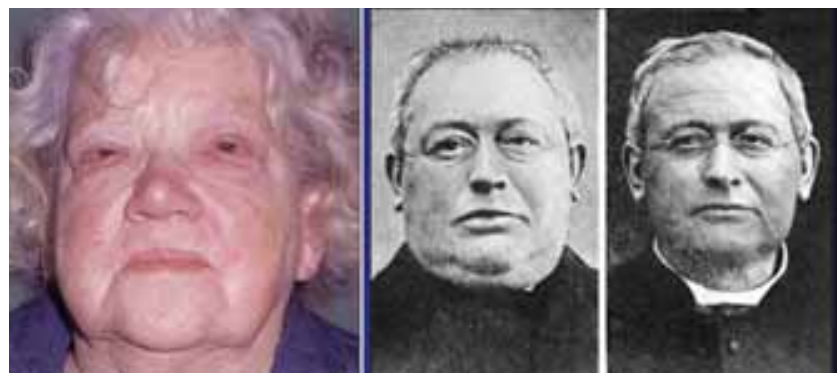

7. ábra

| Hypothyreosisra jellemző facies

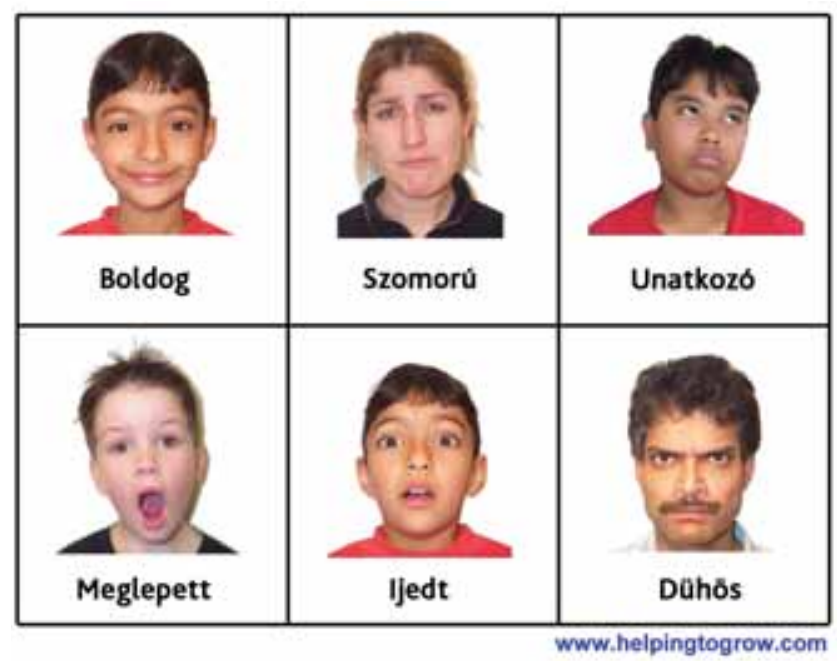

8. ábra

| Akut emocionális arcreakciók

(5. ábra), hiszen a kétféle fizikai terhelésben a dinamikus és a statikus komponens aránya nagyfokban különbözik. Ugyanakkor a két szumóharcos fenotípusa meglepően hasonló, noha a genomjaik különbözőek. A külső környezeti hatás (a kotta) azonossága azt eredményezte, hogy a zongorista hasonló dallamot játszik, az epigenetika által előhívott hasonló gének - a különböző genom ellenére - szinte identikus fenotípust eredményeznek.

A belső környezet minden hyperthyreosis esetén (6. ábra) nagyfokban hasonló, ennek megfelelően a fenotípusok is hasonlóságot mutatnak különböző genom esetén is. Hypothyreosis esetén is ugyanez elmondható (7. ábra).
Az akut emóciók okozta pszichomentális változások az arcmimikában pontosan kifejeződnek (8. ábra). A krónikus emocionális állapot is megjelenik az arckifejezésben: az „arc” a lélek tükre. A delphoi kocsihajtó arca, a madonnaarcok szépséget, erőt, nyugalmat, harmóniát, békét, egészséget, életet sugároznak (9. ábra). Ha valaki ellátogat Püspökszentlászlóra, az apácatemetőbe, akkor arra lesz figyelmes, hogy Anasztázia, Amália, Izabella, Teodóra nővérek 85-90 évet éltek. A krónikus negatív emóciók jelenléte a krónikus stressz állapotra jellemző. A civilizációs stressz, a krónikus frusztráció - számos experimentális és humán megfigyelés alapján - előbb életmódtorzulást okoz: megváltoznak a táplálkozási szokások (szénhidrátdús ételek dominanciája), csökken a fizikai aktivitás, majd testsúlygyarapodás, obesitas jön létre [5]. Utóbbiban obligát módon megjelenik a hyperinsulinaemia, aminek számos szomatikus fenotípusjegye ismert [6]. A krónikus negatív érzelmi állapot nemcsak a metabolikus szindróma, a 2-es típusú diabetes, hanem számos egyéb korállapot halmozott megjelenését okozza $[7,8]$. Ezen esetekben az epigenetika a pszichomentális állapotot - mint kottát - volt képes olvasni.

Felvetődik a kérdés: mi az a mediátor, ami a speciális környezeti ingereket speciális fenotípusra transzformálja? Más szóval: ki valójában a zongorista, mi valójában az epigenetikai mechanizmus megvalósítója?

Ismert, hogy az akut negatív emóció akár pszichogén halált is eredményezhet [9]. Ennek a patomechanizmusát illetően a következő magyarázatok szerepelnek: aritmia, akut coronariaszindróma, adrenalinintoxikáció okozta myocardialis anyagcsere-katasztrófa (akut szívelégtelenség), esetleg perifériás keringési elégtelenség. Mindezen lehetőségekben egyetlen közös található: az extrém fokú autonóm idegrendszeri dystonia, vagyis az autonóm idegrendszer a mediátor a negatív emóció és a pszichogén halál között.

Mi az a mediátor mechanizmus, ami hyper-, illetve hypothyreosisban a specifikus fenotípust kialakítja?

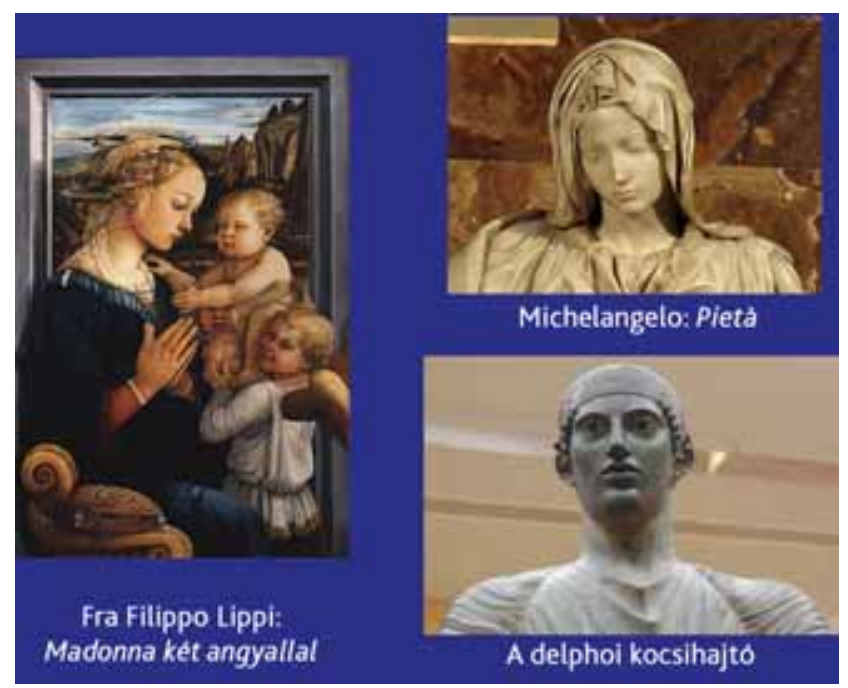

9. ábra | Lelki békét sugárzó arcok 
Hyperthyreosisban és hypothyreosisban egyaránt megfogalmazhatók azon biokémiai, laboratóriumi specifikumok, amelyek a jellegzetes endogén miliőből következnek. Ezen specifikus belső környezet egy specifikus epigenetikai reakciót vált ki: bizonyos gének aktiválódnak, mások inaktiválódnak, ezáltal bizonyos fehérjék de novo szintetizálódnak, más fehérjék szintézise megszünik. Mindezek eredményeképp bizonyos szervek, szervrendszerek - végül az egész szervezet - funkciója, illetve morfológiája specifikusan módosul. Ezt a jelenséget nevezik fenotípusplaszticitásnak [10]. Ennek az alkalmazkodásnak is a mediátora az autonóm idegrendszer, illetve a hozzá kapcsolódó neuroendokrin rendszer: az elsődleges messengereket alkotó extracelluláris hormonok és citokinek, illetve az intracellulárisan ható másodlagos „hírvivők" [11].

Az autonóm idegi hálózat a kapcsolódó neuroendokrin mediátorokkal együtt alkotja azt az anyagi szubsztrátumot, ami epigenetikai transzmitterként müködik, azaz olvasni képes a kottát, azaz a selyei környezetet, és ezen afferens, specifikus információk függvényében „játszik a billentyúkön", azaz specifikus, efferens válasz útján megvalósítja a fenotípusplaszticitást.

Az autonóm idegrendszert alkotó szimpatikus és paraszimpatikus hálózat a szervezet miden sejtjét összeköti egymással, az autonóm idegrendszer a minden sejtet minden sejttel összekötő integrátor. Minden sejt érzékeli elvileg minden más sejt állapotát, és minden sejt hatást gyakorol - elvileg - minden más sejt állapotára. Hasonlóképpen, minden szerv minden más szervvel összeköttetésben van az autonóm idegrendszer útján. Minden szerv minden más szervet érzékel, és minden szerv minden más szervre hatást gyakorol: funkcionális és morfológiai értelemben egyaránt. Ezt bizonyítja az úgynevezett „interorgan szindrómák” (reflexek) egyre szaporodó száma (hepatorenalis, cardiorenalis, renocardialis, hepatopulmonalis, portopulmonalis stb. szindrómák). Vannak olyanok, amelyeknek neve van, és vannak név nélküliek. Utóbbira a Ramadán utáni első étkezés provokálta Brugada-szindróma esete szép példa [12].

A specifikus környezet (külső, belső, pszichomentális) az autonóm idegrendszeren és a hozzákapcsolt neuroendokrin mediátorokon keresztül valósítja meg tehát a specifikus fenotípusalkalmazkodást. Ezen adaptáció egyszerre valósul meg a sejtek szintjén, a szervek, a szervrendszerek és az egész szervezet szintjén, azaz: „ami fenn, az lenn”. Ugyanaz az információ nyer formát a vertikum minden fokán.

Mindez azt jelenti, hogy ugyanaz a környezeti trigger felismerhető a sejt fenotípusa, a szervek fenotípusa, az egész szervezet fenotípusa alapján. Minden szinten ugyanaz a diagnózis állapítható meg. Ennek megfelelően egyes kórformákhoz „összeillő”, specifikus szervi megjelenések és specifikus fenotípusok rendelhetők. Például bal kamrai hypertrophiája van a maratoni futónak és a szumóharcosnak egyaránt: de ez a két bal kamrai hypertrophia egymástól különbözik sejtszinten, biokémiai és

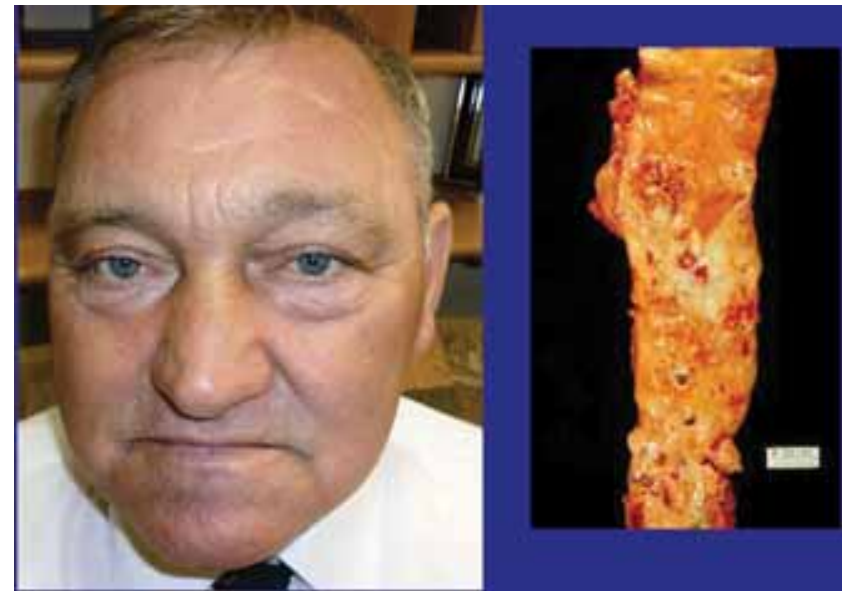

10. ábra |Atheromatosisra utaló facies

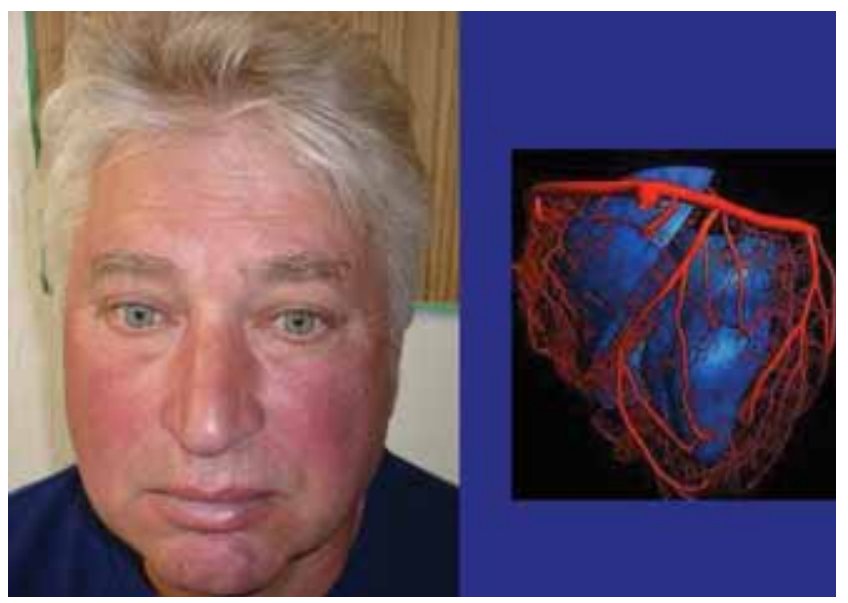

11. ábra | Hyperlipidaemiára utaló facies

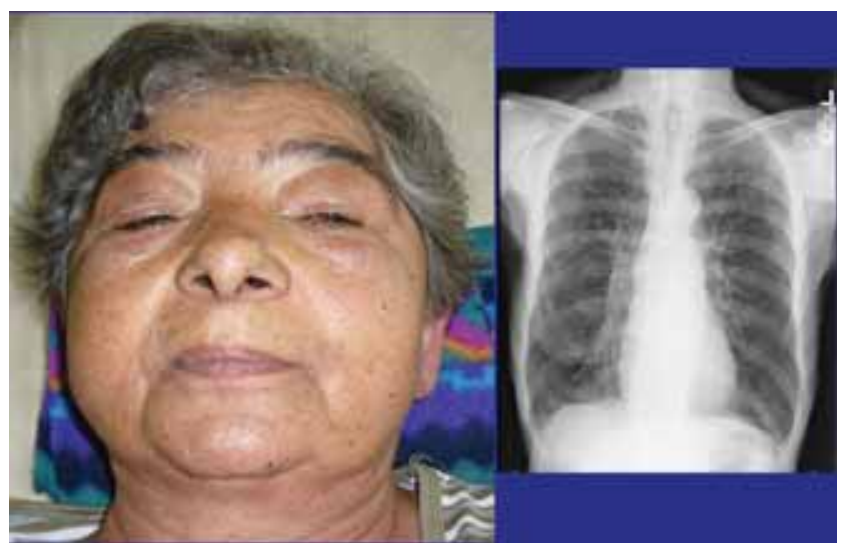

12. ábra | COPD-re utaló facies

ultrastrukturális értelemben egyaránt [13]. Ugyanígy különbözik a kétféle bal kamrai hypertrophia makroszkópos megjelenése a szív-szerv szintjén, és különbözik az egész szervezetet megjelenítő fenotípus is. Egy jellegzetes arcfenotípus mellé rendelhető az atheromatosisra jellemző aortakép (10. ábra), ugyanígy a hyperlipidaemi- 


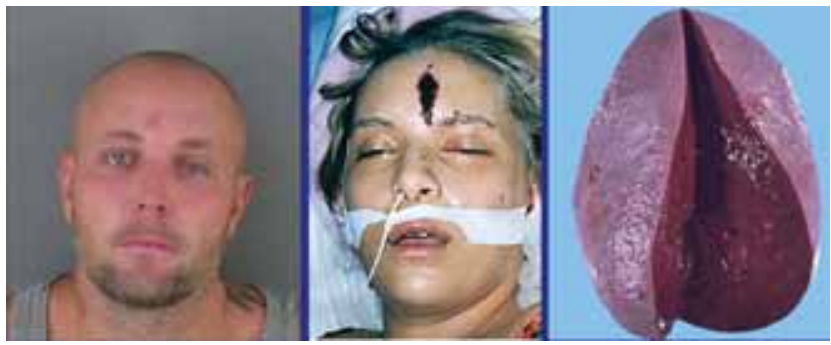

13. ábra | Szepszisre jellemző facies

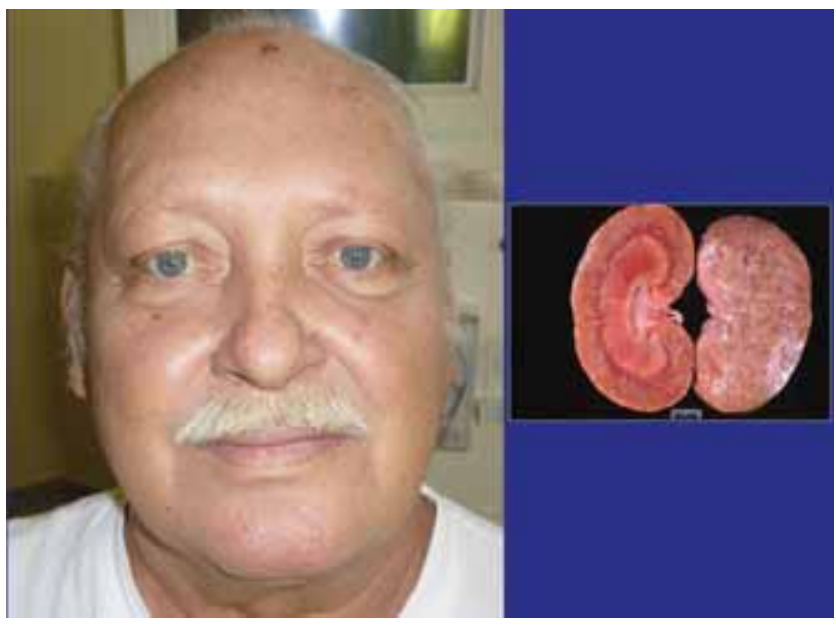

14. ábra | Vesebetegségre jellemző facies

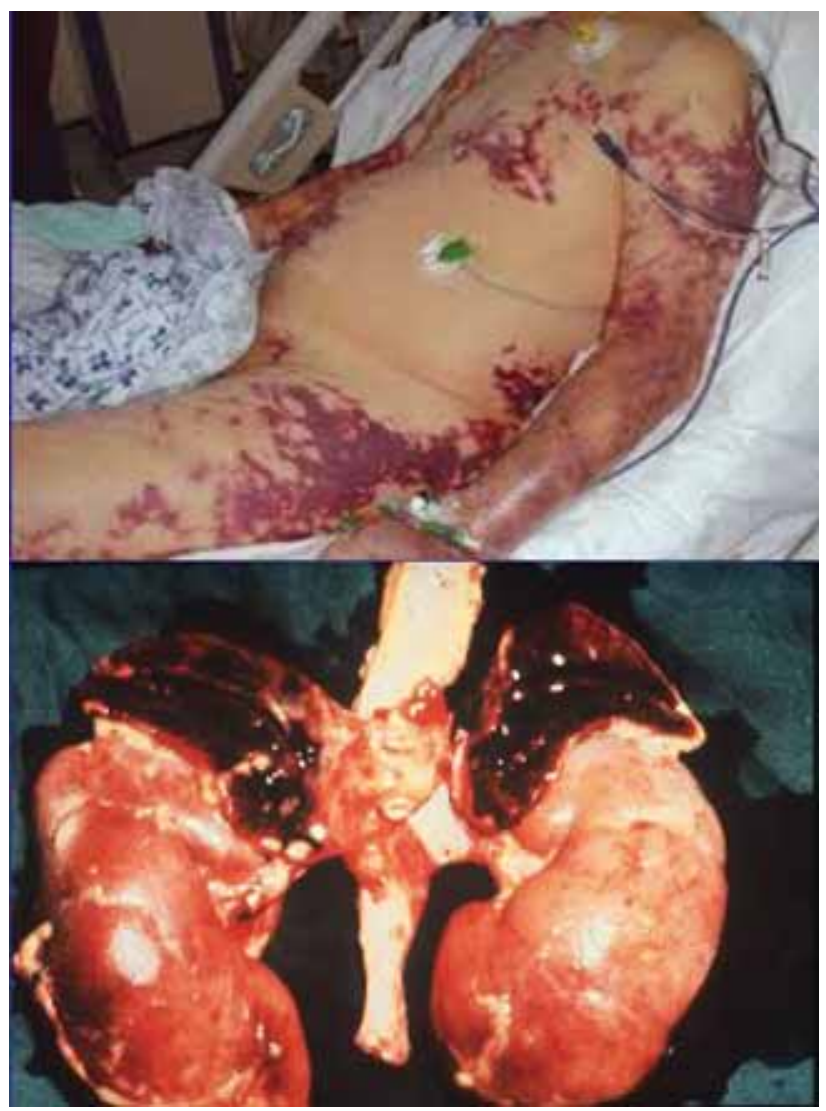

15. ábra
| Endotoxinsokk ás arc mellé a coronariabetegség képe (11. ábra). A COPD-s arc és tüdőkép (12. ábra), a szeptikus arc és szeptikus lép képe (13. ábra), a vesebetegfacies és végstádiumú vese képe (14. ábra) vagy az endotoxinsokkra jellemző bőrvérzések és a mellékvese-apoplexia (15. ábra) összetartozása is kimondható.

Bódis Lóránt kardiológus apex-ballisztokardiográfiával foglalkozott az 1970-es években. A szívcsúcs mechanikus mozgását megjelenítő analóg görbéből nemritkán meg tudta mondani azt, hogy a betegnek ulcusbetegsége van. Hasonlóan, van echokardiográfus, aki a látott képból a metabolikus szindróma, a 2-es típusú diabetes jelenlétére tud következtetni.

Az elmondottak tudományos megértéséhez szükséges az úgynevezett Gestalt-psychologie (psychology) fogalmának ismerete [14]. Ez azt jelenti, hogy az Egész nem azonos a részek összegével. Az Egész több, mint a részek összege, az Egész prioritással bír a részek összege felett. Mindez azt mondja, hogy „ami fenn, az lenn”, de azt is, hogy ami fenn van, az több annál, mint ami lenn van. Azaz: az Egész fenotípusa többletinformációt hordoz a részek fenotípusával szemben. Ez a blikk diagnosztika tudományos megalapozottságát egyértelmúen támogató adat.

Tabár László, aki a mammográfia világszerte elismert pápája, egy Pécsen tartott Romhányi-emlékelőadáson az emlőcarcinoma prognosztikai lehetőségeiről azt állította, hogy az emlőrák semmiféle cito-, hisztomorfológiai, hisztokémiai, cito-, hisztogenetikai vizsgálati adata nem rendelkezik olyan prognosztikai értékkel, mint az egész emlőt megjelenítő mammográfiás vagy ultrahangos kép. Nevezetesen: a diszharmónia, a szerv morfológiai dezintegrációjának a foka a legfontosabb prognosztikai tényezô. Mindez azt jelenti, hogy az Egészról alkotott szubjektív benyomás információértéke több lehet, mint bármely részlet bármely objektíven mérhető paramétereinek értéke. Más szóval: „minél mélyebbre megyünk”, valóban annál többet tudhatunk, de ezzel egy időben valami még fontosabbat el is veszíthetünk. Ennek alapján kijelenthető, hogy a szubjektív benyomás és az objektív evidenciák viszonyának átértékelése is szükségessé válik, mert bizonyos esetekben az „érzem” többet jelenthet, mint az „értem.”

Felmerül a kérdés, melyik környezeti tényező (külső, belső, pszichomentális tényező) a „legerősebb kottaíró”, a legerősebb szomatikus állapotot befolyásoló tényező? B. Lown Nobel-békedíjas orvos a „The lost art of healing" címú könyvében [9] leírja annak a 35 éves bűnözőnek a történetét, akit az Amerikai Egyesült Államok egyik államában halálra ítéltek, és az ottani törvényeknek megfelelően megválaszthatta a halálnemét. Fájdalommentes halálformát, az elvéreztetést választotta. B. Lown jelenlétében lefektették, bekötötték a szemét, karján vénát szúrtak, amire infúziót kötöttek. Ezzel egy időben egy másik infúzióból - jól hallhatóan - egy tálba csepegtették az infúziós oldatot. Az egészséges 35 éves geng- 
szter - abban a tudatban, hogy elvérzik - meghalt. A hite, a hit romboló ereje megölte az egészséges testet.

Jacalyn Duffin ateista orvosnő a "Medical miracles” címú könyvében [15] azt állítja a vatikáni kanonizációs jegyzőkönyvek áttanulmányozása után, hogy kétséget kizáróan léteznek csodás gyógyulások, amelyeket a tudomány magyarázni nem képes. Ezen esetekben a hit teremtő ereje meggyógyította a beteg testet. Ezekben az esetekben is az autonóm idegrendszer alkotja az anatómiai szubsztrátumot a lélek és a test között: a szubjektív hit, a szubjektív érzés, a szubjektív gondolat az autonóm idegrendszer hídján keresztül válik objektív, materiális valósággá.

Léteznek tehát csodás gyógyulások, amelyek a szubjektív hit létével állnak kapcsolatban. A hit ezen foka kétségtelenül az emberben van, de akarattal nem teremthető meg, azaz nincs az ember hatalmában. Akkor kinek a hatalmában van? A teremtő vagy éppen a romboló hit egyaránt a misztérium világába tartozik.

Mindezek alapján kijelenthetó, hogy a specifikus környezeti ingerek, például: a belső környezet korral járó változásai szükségszerúen megjelennek az egész szervezet fenotípusában ugyanúgy, mint ahogy a külső környezet ingerei is manifesztálódnak. Hasonlóképpen a lélek állapotváltozásai is kifejezést nyernek a fenotípusban, a szervek állapotában. Mindez az autonóm idegrendszeren keresztül epigenetikai mechanizmussal valósul meg. Ez azt jelenti, hogy a fenotípus - tudományosan indokolható módon - hordozza az epigenetikai lenyomatot. $\mathrm{Az}$ is ismert, hogy bizonyos genetikai állapotok (például 2 l-es triszómia, Down-kór) szintén a specifikus fenotípusjegyek alapján felismerhetők. Kijelenthető tehát, hogy a fenotípus genetikai és epigenetikai lenyomat egyszerre. Ezen megállapítás tudományosan megalapozottnak nevezhető.

Felvetődhet még a blikk diagnosztika szenzitivitásának kérdése. Nevezetesen, a hozzáférhető laboratóriumi diagnosztika és a blikk diagnosztika pozitivitásának idóbeli viszonya. Például egy pajzsmirigybetegségre jellemzőnek mondható facies előre jelzése már akkor nyilvánvaló, amikor semmiféle laboratóriumi teszt nem támogatja a diagnózist. A családi anamnézis egyidejü pozitivitása tovább emeli a gyanú megalapozottságát [16].

\section{A fenotípushasonlóságról}

Ha tehát egy azonos vagy hasonló fenotípussal találkozunk, akkor a kérdés az, hogy ennek genetikai vagy epigenetikai oka van-e? Az összefüggés ugyanis kétirányú: ahogy az azonos genetika vagy az azonos selyei környezet azonos fenotípust hív elő, a kérdés úgy is feltehetó, hogy az azonos fenotípus hátterében azonos genetikai vagy azonos környezeti tényező szerepel-e okként? Noha a genetikai rokonság - elsố megközelítésben - képtelenségnek tûnik, az alábbi gondolatmenet azonban mégis elgondolkoztató. Minden embernek van két szülóje, minden szülőnek ugyanígy két ôse és így tovább. Ez azt jelenti, hogy a $2^{0}, 2^{1}, 2^{2}, 2^{3} \ldots 2^{10}$ generáció esetén eljutunk a $10^{3}$ számú ôshöz $\left(2^{10}=1024 \cong 10^{3}\right)$, a 20 . generáció esetén: $2^{20} \cong 10^{6}$, a 30 . generációnál: $2^{30} \cong 10^{9}$, azaz 1 milliárd őshöz. Ha $10^{7}$ számú egyedból (10 millió lakos van Magyarországon) indulunk ki, akkor ez: $10^{7} \times 10^{9}$ $=10^{16}$, azaz 10 milliószor 1 milliárd. 30 generációt viszszaszámolva - és 1 generációt 30 évnek véve: $30 \times 30$ év = 900 év ( 1000 év) az eredmény. Ez azt jelentené, hogy a honfoglalás idején a Kárpát-medencében 10 milliószor l milliárd ôst kellene feltételezni. Ez a szám olyan nagy, hogy akkor sem lehet reális, ha visszamenőleg minden generációban - minden családon belül - nagyszámú testvért tételezünk fel. Ennek alapján arra a következtetésre kell jutnunk, hogy mi mindnyájan - jó néhány generációval korábban - egymással genetikai rokonságban állunk. Ami pedig az azonos vagy hasonló fenotípust magyarázó esetleges epigenetikai mechanizmust illeti, a „külső és a belső környezet" oki szerepén kívül nem vethetô el az azonos „pszichomentális környezet” (a lélekállapot) testteremtő ereje sem (az „arc” a lélek tükre).

Robert Duwallról írták le, hogy az 1990-es évek elején, amikor a Sztálin-filmszerepre készült, a Sztálinról szóló írások, kép- és hanganyagok birtokában „önkéntes számû́zetésbe" vonult, majd pár hónap után - ismerôsei döbbenetére - Sztálinra jellemző fenotípussal jelent meg. Az „arc” a lélek tükre. A homoszexuálisok sajátos lélekalkata is fenotípus és mozgáskoordinációs azonosságot eredményez. Mindezek alapján joggal merül fel, hogy az úgynevezett pszichoszomatikus kórképek köre jelentősen kiszélesíthető.

A fent elmondottakat figyelembe véve a blikk diagnosztika, az úgynevezett fiziognómia $[16,17]$ nem nevezhető megalapozatlan módszernek, nem kitiltandó a klinikai gyakorlatból, sôt hasznossága egyértelmú, oktatása pedig szükségszerünek nevezhető.

\section{Irodalom}

[1] Selye, H.: A syndrome produced by diverse nocuous agents. Nature, 1936, 138, 32.

[2] Selye, H.: Stress without distress. J. B. Lippincott, Philadelphia, PA, 1974.

[3] Diller, L.: Clinical practice. Adult primary care after childhood acute lymphoblastic leukemia. N. Engl. J. Med., 2011, 365(15), 1417-1424.

[4] Brotman, D. J., Golden, S. H., Wittstein, I. S.: The cardiovascular toll of stress. Lancet, 2007, 370(9592), 1089-1100.

[5] Adam, T. C., Epel, E. S.: Stress eating and the reward system. Physiol. Behav., 2007, 91(4), 449-458.

[6] Simon K., Gyulai M., Tamás Gy., et al.: Screening for type II diabetes-candidates. Am. J. Med., 1999, 106(4), 489-491.

[7] Kosztolányi, Gy.: Hypothesis: epigenetic effects will require a review of the genetics of child development. J. Community Genet., 2011, 2(2), 91-96.

[8] Jirtle, R. L., Skinner, M. K.: Environmental epigenomics and disease susceptibility. Nat. Rev. Genet., 2007, 8(4), 253-262.

[9] Lown, B.: Mind and heart. In: Lown, B. (ed.): The lost art of healing. The Ballantine Publisching Group, New York, 1999, 29-47.

[10] Feinberg, A. P.: Phenotypic plasticity and the epigenetics of human disease. Nature, 2007, 447(7143), 433-440. 
[11] Johnstone, S. E., Baylin, S. B.: Stress and the epigenetic landscape: a link to the pathobiology of human diseases? Nat. Rev. Genet., 2010, 11(11), 806-812.

[12] Talib, S., van de Poll, S.W.: Brugada syndrome diagnosed after Ramadan. Lancet, 2013, 382(9886), 100.

[13] Bernardo, B. C., Weeks, K. L., Pretorius, L., et al.: Molecular distinction between physiological and pathological cardiac hypertrophy: experimental findings and therapeutic strategies. Pharmacol. Ther., 2010, 128(1), 191-227.

[14] Meyers, M. A.: Introduction 5. In: Meyers, M. A. (ed.): Happy accidents. Serendipity in modern medical breakthroughs. Arcade Publishing, New York, 2007, 1-25.
[15] Duffin, J.: Conclusion (religion, medicine and miracles) In: Duffin, J.: Medical miracles. Doctors, saints, and healing in the modern world. Oxford University Press, New York, 2009, 183-190.

[16] Simon, $K .:$ Mortality in elderly patients with subclinical hyperthyroidism. Letter to editor. Lancet, 2002, 359(9308), 798-799.

[17] Humphrey, G.: The psychology of the Gestalt. J. Educ. Psychology, 1924, 15(7), 401-412.

(Simon Kornél dr. Siófok, Semmelweis u. 1., 8600 e-mail: simon.kornel@siokorhaz.hu)

Az Orvosi Hetilap 2015, 156, 952. oldalán (23. szám) megjelent OH-Kvízre öt helyes megfejtés érkezett.

A beküldők: Dr. Bíró László (Budapest), Dr. Kónya Csaba (Budapest), Dr. Pallos Ágnes (Budapest), Dr. Somogyi Erzsébet (Miskolc) és Dr. Sósik Ibolya (Budapest).

A nyerteseknek szívből gratulálunk.

A nyereményüket - egy, az Akadémiai Kiadó web áruházában kedvezményes vásárlásra jogosító kupont - e-mailen küldjük el. 